Int. J. Dev. Biol. 48: 663-670 (2004)

doi: $10.1387 /$ ijdb.041861ed

Original Article

\title{
Development of the dendrobatid frog Colostethus machalilla
}

\author{
EUGENIA M. DEL PINO*, MARÍA-EUGENIA ÁVILA, OSCAR D. PÉREZ, MARÍA-SOLEDAD BENÍTEZ, INGRID \\ ALARCÓN, VANESSA NOBOA and IVÁN M. MOYA
}

Escuela de Ciencias Biológicas, Pontificia Universidad Católica del Ecuador, Quito, Ecuador.

\begin{abstract}
To provide a developmental correlate with other frogs, we prepared a normal table of development for the dendrobatid, Colostethus machalilla and analyzed the morphology of its early development. This frog reproduces in captivity and deposits moderately sized eggs $(1.6 \mathrm{~mm}$ in diameter) in terrestrial nests. The father guards the embryos until tadpole hatching. We divided development until hatching into 25 stages and implemented methods for in vitro culture of the embryos. The external and internal morphology of embryos were evaluated by observations in whole mount and in sections. Neural, notochord and somite specific antibodies were used to analyze gene expression patterns by immunostaining of embryos. Embryonic development of $C$. machalilla is slow and deviates from Xenopus laevis. In $C$. machalilla the elongation of the notochord, neural plate and somite formation occur after blastopore closure, possibly due to a delay in the dorsal convergence and extension movements. The gastrula of $\boldsymbol{C}$. machalilla also deviates from $X$. laevis. The archenteron remains small until blastopore closure, where small cells accumulate at the blastopore lips. Simultaneously, the blastocoel roof thins until it becomes a monolayer of cells. Although $C$. machalilla does not form an embryonic disk, its thick blastopore lips resemble the embryonic disk of the marsupial frog Gastrotheca riobambae and represent an interesting deviation from the gastrulation pattern observed in $X$. laevis.
\end{abstract}

KEY WORDS: blastula, Eleutherodactylus coqui, Gastrotheca riobambae, gastrula, neurula

\section{Introduction}

Dendrobatid frogs (Dendrobatidae) occur in Central and South America and have a terrestrial mode of reproduction (reviewed in Duellman and Trueb, 1986). Members of this frog family can be successfully raised in captivity (Zimmermann and Zimmermann, 1987), a feature that makes the study of their development attractive. This family includes the poison arrow frogs, which are known for their skin toxins and unusual colors (Daly, etal., 1987; QuiguangoUbillús, 2000). The phylogenetic relationships of these frogs are given in Santos et al. (2003). Not all dendrobatids, however, are poisonous or have bright colors. For example, Colostethus machalillais a dark brown and non-poisonous dendrobatid of about $17 \mathrm{~mm}$ in length, that occurs in dry western lowland forests of Ecuador (Coloma, 1995). These frogs are active during the day and display complex reproductive behavior (Quiguango-Ubillús, 2000). The male is territorial and attracts the female to his chosen nest with a characteristic call. Amplexus takes place on the ground; the eggs are typically deposited on the soil or under dry leaves. After amplexus, the female leaves the nest and the father protects the developing embryos against intruders with elaborate aggressive behavior. At the time of hatching, the male carries the tadpoles on its back into the water where tadpole growth and metamorphosis occur (Quiguango-Ubillús, 2000). In spite of their unusual mode of reproduction, not much is known about the early development of dendrobatid frogs, except for the expression of Brain C. machalilla (Benítez and del Pino, 2002).

The developmental variations found in different frogs are natural experiments that enlarge the hypotheses resulting from the study of Xenopus laevis. For example, Braexpression during C. machalilla early development is novel when compared to the patterns found in X. laevis, Gastrotheca riobambae and Eleutherodactylus coqui (Smith et al., 1991; Gont et al., 1993; del Pino, 1996; Ninomiya et al., 2001; Benítez and del Pino, 2002). Although Bra expression in the notochord is highly conserved, deviations were detected in the marginal zone of the analyzed frogs (Smith et al., 1991; del Pino, 1996; Ninomiya et al., 2001; Benítez and del Pino, 2002). In $X$. laevis, Bra is expressed in the prospective mesoderm and is an immediate early response to mesoderm induction (Smith, et al., 1991; Ibrahim and Winklbauer, 2001). Colostethus machalilla presents a transient superficial ring of Bra positive nuclei in the

Abbreviations used in this paper: Bra, Brachyury; NCAM, neural cell adhesion molecule; s, stage.

\footnotetext{
*Address correspondence to: Dr. Eugenia M. del Pino. Pontificia Universidad Católica del Ecuador, Escuela de Ciencias Biológicas, Avenida 12 de Octubre y Patria, Apartado 17-01-2184, Quito, Ecuador. Fax: +593-2229-1687. e-mail: edelpino@puce.edu.ec
} 
marginal zone of the blastula, followed by a deep signal around the blastopore of the mid gastrula (Benítez and del Pino, 2002). Due to these variations, it is uncertain whether Bra expression in the marginal zone recognizes the prospective mesoderm in C. machalilla (Benítez and del Pino, 2002). Therefore, fate mapping of the prospective mesoderm in this and other frog species is crucial. To facilitate the comparisons, we provide a table of developmental stages of Colostethus machalilla and a morphological description of its early development.

\section{Results}

\section{Reproduction in captivity}

In terraria, males displayed nesting territoriality over empty plastic film containers. The transparent containers were used more often than black ones as nesting sites. Nevertheless, plant leaves and secluded places of the terrarium floor were also used as nests. Males loudly called to invite females. After elaborate courtship
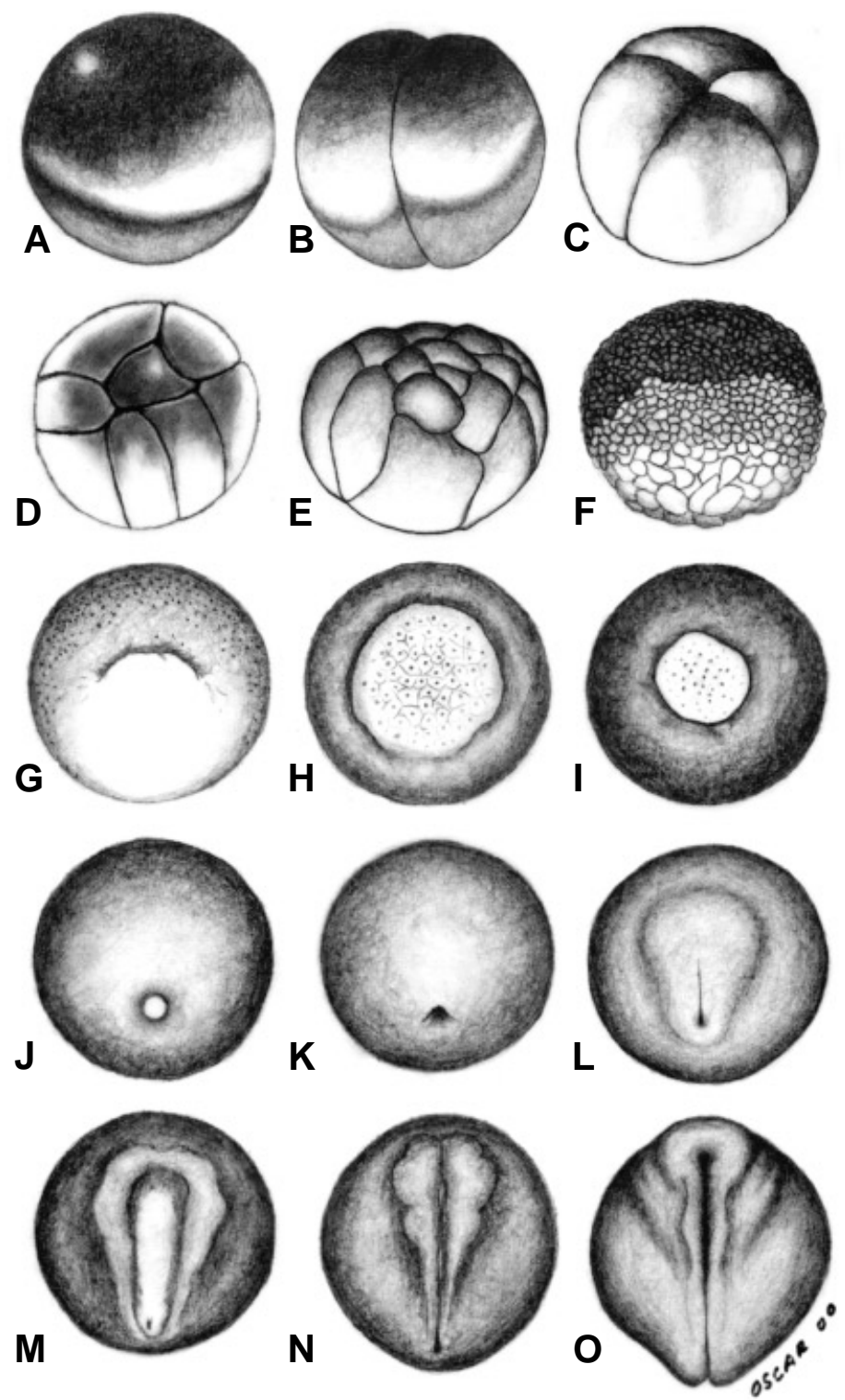

behavior, amplexus occurred and a clutch of eggs was deposited, which were removed for the study of embryos. Females laid eggs variably throughout the year, there were periods when up to 5 eggclutches were found every week, whereas other times few or no eggs were found in the terraria. We could not estimate reproductive cycles of the females because several female frogs were maintained in each terrarium. Egg clutches consisted of 15 eggs on average (range of 8-21 eggs, based on the study of 72 clutches of eggs). In the morning we discovered clutches of blastula stage embryos, whereas early cleavage embryos were found after 14:00 hours. This indicates that amplexus and fertilization occurred around noon or later. Careful monitoring of the calling male led to the discovery of a nest at the time of fertilization.

\section{Developmental stages of C. machalilla}

Development of $C$. machalillatook 19-20 days from fertilization until the hatching of tadpoles both when the embryos were cared by the father in the nest and when cultured in a humid chamber. Development became slightly accelerated in 15\% Steinberg's solution. The development of $C$. machalilla was divided into 25 stages (Figs. 1-2; Table 1). The $X$. laevis staging criteria from fertilization to the early neurula were applied to define the early stages of $C$. machalilladevelopment (Table 1; s. 1-14 of Nieuwkoop and Faber, 1994). After s. 14, C. machalilla development deviates from $X$. laevis and we staged the embryos according to the generalized table of frog development (Gosner, 1960). Free-living tadpoles were not analyzed.

Cleavage and the blastula (s. 1-9): The egg of C. machalilla measured $1.6 \mathrm{~mm}$ in diameter (mean of $18 \mathrm{eggs}$ ) and the egg volume was about 2.4 times larger than in $X$. laevis. The $C$. machalilla egg is larger than in $X$. laevis and smaller than in $G$. riobambae and $E$. coqui (eggs of $1.3,3$ and $3.5 \mathrm{~mm}$ in diameter,

Fig. 1. The early development of $C$. machalilla (stages 1-16). (A-F) Lateral view of cleavage and blastula. The animal pole is oriented towards the top. (G-K) The gastrula, viewed from the vegetal pole, with the dorsal side oriented toward the top. (L-O) The late gastrula and the neurula in dorsal view, with the anterior region oriented toward the top. (A) The fertilized egg (s. 1). The animal pole contains dark pigment. The sperm entry point is seen as a small clear area in the animal region to the left. Opposite, the gray crescent is visible. (B) Stage 2: the two cell stage. The first cleavage furrow passes from the animal to the vegetal pole. (C) Stage 3: the four cell stage. The second cleavage furrow is perpendicular to the first one and also passes from the animal to the vegetal pole. (D) Stage 4: the eight cell stage. Cleavage is irregular. (E) Stage 6: the 32-cell stage. The embryo in this figure had less than 32 cells. (F) Stage 8: medium-cell blastula. (G) Stage 10: early gastrula. The dorsal blastopore lip can be observed in this ventral view. (H) Stage 11: mid gastrula. The yolk plug is large and measures about half of the embryo's diameter. Involution through the ventral blastopore lip had just begun (bottom of the figure). (I) Stage 12: late gastrula. The maximum diameter of the yolk plug is about a third of the embryo's diameter. (J) Advanced s. 12: late gastrula with a small yolk plug. (K) Stage 13: slit blastopore stage. The yolk plug has been retracted inside the embryo. (L) Advanced s. 13: the neural plate is visible. The central line may represent the neural groove. (M) Stage 14: the early neurula stage. The neural folds become elevated. (N) Stage 15: the mid neurula stage. The neural folds approach each other. (0) Stage 16: closure of the neural tube. In this drawing, the neural tube is still open in the posterior region of the embryo. The branchial neural crest protrudes as two major bulges on each side of the head. The age of embryos is given in Table 1. The egg diameter is about $1.6 \mathrm{~mm}$. 
Fig. 2. The tail bud stage, development of the gills and the tadpole at hatching (s. 17-25). Allembryos are oriented with the head towards the left. Dorsal is oriented toward the top in (A). (B-C, G-I) Embryos in dorsal view. (D-F, J-K) Detail of the gill development in lateral view with the head oriented towards the left. (L-N) The tadpole at hatching (s. 25). (A) The tail bud (s. 17). The C. machalilla embryo develops on top of a large mass of yolk and the head and the tail have become separated from the yolk. The branchial arches protrude on the sides of the head. (B-I) Development of the external gills (s. 18-23). (B) The early s. $18 \mathrm{em}$ bryo: the branchial arches protrude on the sides of the head. The eye vesicles are small. (C) Stage 18 embryo: the branchial
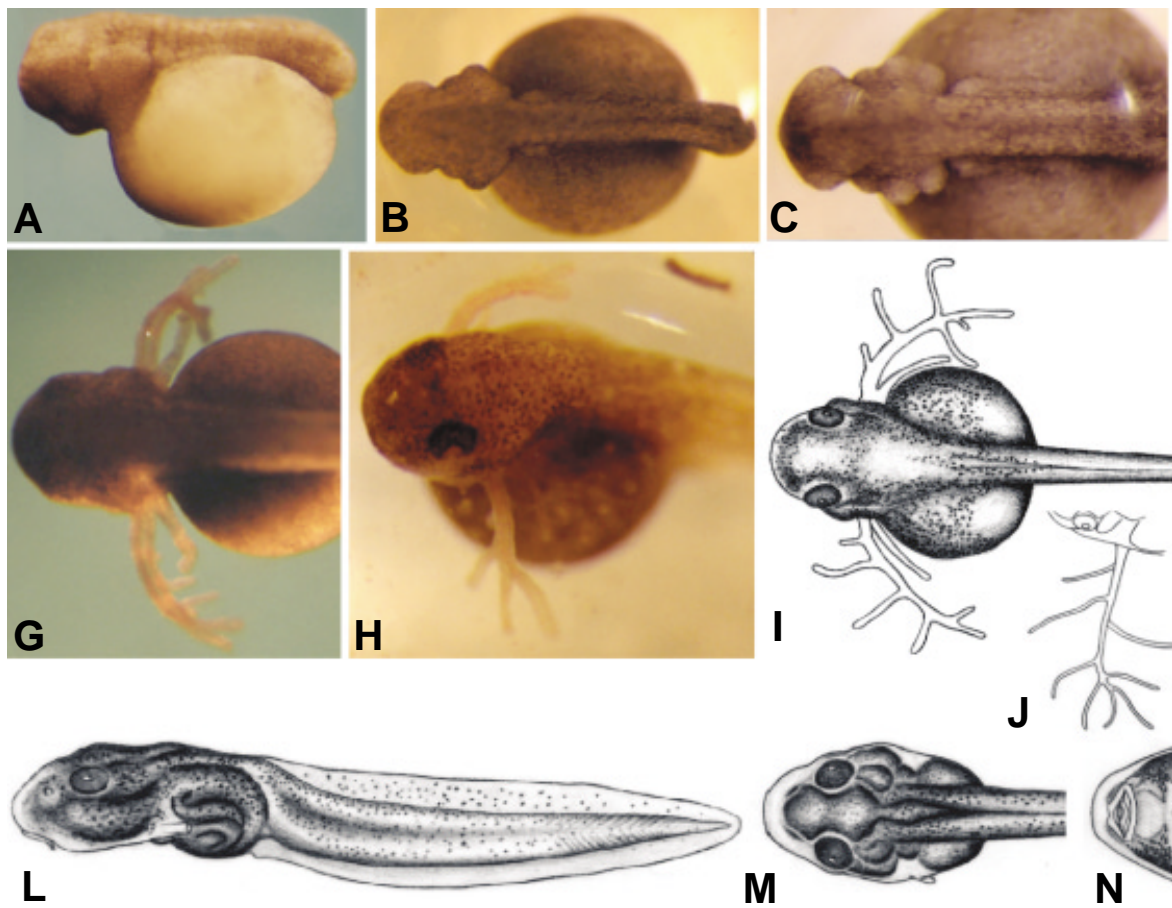

M

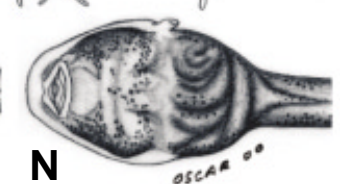

arches and the pronephros bulge on the sides of the body. The eye vesicles are slightly larger than in (B). (D) Detail of the gill bud region in the early s. 19: the buds of first pair of external gills protrude from the branchial region. (E) Detail of the gill bud region in s. 19: the buds of the first pair of external gills become branched and the buds of the second pair of external gills are visible. (F) Detail of the gill bud region in s. 20: the two pairs of external gills are small. The first pair of gills has at least four branches. The second pair remains unbranched. (G) Stage 21: the first pair of external gills has the characteristic number of six branches for this species. The second gill pair remains small and unbranched. The body of the embryo has elongated considerably. The eyes remain small and unpigmented. (H) Stage 22: the embryo has dark pigment in the body and in the eyes. The external gills enlarge. (I) Stage 23: full development of the external gills. In C. machalilla, the first pair of external gills has 6 branches, which at this stage are fully extended. The second pair of external gills is always smaller and unbranched. The eyes and the body of the embryo contain dark pigment. The embryo has a large tail. (J) Detail of the first external gill pair in Epipedobates tricolor. The first gill pair in this frog develops a total of eight branches. (K) Detail of the first external gill pair in C. marchesianus. In this frog, the first gill pair develops only four branches. As in C. machalilla, the second pair of gills is small and unbranched in both frogs (not shown). (L) Lateral view of the C. machalilla embryo at hatching (s. 25). The body is pigmented and the embryo has the appearance of a tadpole. The coils of the intestine and the tail fin are visible. (M) Dorsal view of the head at hatching (s. 25). The large eyes and the spiracle (on the left of the body) are visible. (N) Ventral view of the head at hatching. The mouth has rows of pigmented teeth. The coils of the intestine and the spiracle are visible. The embryos grow from an egg of $1.6 \mathrm{~mm}$ to a tadpole of $10 \mathrm{~mm}$ in length. The tadpole head measures about $3 \mathrm{~mm}$ in length.

respectively; reviewed in del Pino and Elinson, 2003). The animal hemisphere is darkly pigmented (Fig. 1A). The cortical movements associated with sperm entry changed the distribution of pigment and 1.5 hours after fertilization a gray crescent became evident in the equatorial region (Fig. 1A; Table 1). We included the formation of the gray crescent within s. 1 of $C$. machalilla (Fig. 1A; Table 1), although Gosner (1960) recognizes the gray crescent as a separate stage (Table 1 ). The formation of a gray crescent in $C$. machalilla eggs (Fig. 1A) suggests that rotation of the egg cortex during the first cell cycle is likely involved in dorsal axis determination, as in $X$. laevis (Vincent et al., 1986).

The $C$. machalilla first cell cycle took about 3 hours at room temperature $\left(18-23^{\circ} \mathrm{C}\right.$; Table 1$)$. The first cleavage furrow originated in the animal pole and gradually divided the egg into two blastomeres (Fig. 1B; Table 1). Cleavage in C. machalilla was holoblastic and synchronous, requiring about 1 hour for each cleavage cycle (Table 1). Formation of the second cleavage furrow began after the first division was completed (Fig. 1C; Table 1). Similarly, the third cleavage furrows became visible after the previous division was completed. At the eight-cell stage, most embryos cleaved irregularly (Fig. 1D; Table 1), others displayed 4 small animal micromeres and 4 large vegetal macromeres. At the next stages (s. 5-6), the embryos cleaved synchronously into 16 and 32 cells, respectively (Fig. 1E; Table 1). In the blastula, the dark animal micromeres were very small, in comparison with the large and pale yellow macromeres of the vegetal region (s. 7-9; Fig. 1F; Table 1).

Gastrulation (s. 10-13) and neurulation (s. 14-16): A dorsal blastopore lip was formed in s. 10, as in X. laevis (Fig. 1G; Table 1). The dorsal blastopore lip was observed at the boundary between the slightly pigmented blastomeres of the sub-equatorial region and the large and yolky vegetal cells (Fig. 1G). In s. 11, the blastopore surrounded a large yolk plug that measured about half of the embryo's diameter (Fig. $1 \mathrm{H}$; Table 1). In s. 12, the blastopore gradually closed. The yolk plug that measured less than one third of the embryo's diameter became smaller (Fig. 1I, J; Table 1). In s. 13, the yolk plug retracted inside the embryo and the closed blastopore looked like a small slit (Fig. 1K, L; Table 1). In advanced s. 13 embryos, what may be the neural groove and the outline of the neural plate became visible (Fig. 1L). The neural folds elevated 
in s. 14 embryos (Fig. 1M). The neural folds gradually closed in the midline during s. $15-16$ (Fig. $1 \mathrm{~N}, \mathrm{O}$; Table 1). The embryos of $C$. machalilla did not develop the cement gland.

The tail bud stage, development of the external gills and operculum (s. 17-25): In s. 17, the tail bud and the head region protruded beyond the large yolky endoderm (Fig. 2A; Table 1). In s. 18, the embryos had muscular activity (Fig. 2 B,C; Table 1). The heart began to beat in s. 19 (Table 1). Blood circulation to the external gills was visible in s. 20 . In s. 22 , blood circulation was detected in the transparent tail fin (Table 1). In s. 18-25, the tail gradually elongated and the embryo acquired the appearance of a

\section{TABLE 1}

\section{STAGES OF DEVELOPMENT IN C. MACHALILLA IN COMPARISON} TO $X$. LAEVIS AND OTHER FROGS

\begin{tabular}{|c|c|c|c|c|c|}
\hline \multicolumn{3}{|c|}{ Stage ${ }^{1}$} & \multirow[t]{2}{*}{ Characteristics of $C$. machalilla embryos } & \multicolumn{2}{|c|}{ Age $^{2}$ in: } \\
\hline C & $\mathbf{x}$ & G & & Hours & Days \\
\hline 1 & 1 & 1 & Fertilization. & 0.0 & \\
\hline 1 & - & 2 & Gray crescent (Fig. 1A). & 1.5 & \\
\hline 2 & 2 & 3 & Two cell stage (Fig. 1B). & 3.3 & \\
\hline 3 & 3 & 4 & Four cell stage (Fig. 1C). & 4.6 & \\
\hline 4 & 4 & 5 & Eight cell stage (Fig. 1D). & 5.4 & \\
\hline 5 & 5 & 6 & Sixteen cell stage (not shown). & 6.1 & \\
\hline 6 & 6 & 7 & Thirty-two cell stage (Fig. 1E). & 6.8 & \\
\hline 7 & 7 & 8 & Large-cell blastula (not shown). & 14.1 & \\
\hline 8 & 8 & - & Medium-cell blastula (Fig. 1F). & 19.4 & \\
\hline 9 & 9 & 9 & Advanced blastula (not shown). & & 1.1 \\
\hline 10 & 10 & 10 & $\begin{array}{l}\text { Early gastrula. The dorsal blastopore lip is formed } \\
\text { (Fig. 1G). }\end{array}$ & & 1.4 \\
\hline 11 & 11 & 11 & $\begin{array}{l}\text { Mid gastrula with a yolk plug that measures about } 1 / 2 \\
\text { the embryo's diameter (Fig. } 1 \mathrm{H} \text { ). }\end{array}$ & & 1.9 \\
\hline 12 & 12 & 12 & $\begin{array}{l}\text { Late gastrula with a yolk plug that is } 1 / 3 \text { the embryo's } \\
\text { diameter or smaller (Fig. } 11, \mathrm{~J} \text { ). }\end{array}$ & & 3.0 \\
\hline 13 & 13 & 13 & $\begin{array}{l}\text { Slit blastopore stage (Fig. 1K). The neural plate } \\
\text { becomes visible in the late stage } 13 \text { (Fig. } 1 \mathrm{~L}) \text {. }\end{array}$ & & 4.1 \\
\hline 14 & 14 & 14 & Early neural fold stage (Fig. 1M). & & 4.6 \\
\hline 15 & 16 & 15 & Mid neural fold stage (Fig. $1 \mathrm{~N}$ ). & & 5.4 \\
\hline 16 & 20 & 16 & Closure of the neural tube (Fig. 10). & & 7.3 \\
\hline 17 & 24 & 17 & $\begin{array}{l}\text { Tail bud stage. The tail bud and the head region } \\
\text { protrude beyond the yolky endoderm (Fig. } 2 \mathrm{~A} \text { ). }\end{array}$ & & 8.0 \\
\hline 18 & 26 & 18 & $\begin{array}{l}\text { Muscular activity. The branchial arches protrude on } \\
\text { the sides of the head. The eye vesicles are small } \\
\text { (Fig. 2B, C). }\end{array}$ & & 8.5 \\
\hline 19 & 33 & 19 & $\begin{array}{l}\text { The heart beats and the gill buds are visible } \\
\text { (Fig. 2D, E). }\end{array}$ & & 9.5 \\
\hline 20 & 40 & 20 & $\begin{array}{l}\text { Circulation to the external gills. The first gill pair has } \\
\text { four or more branches (Fig. } 2 F \text { ). }\end{array}$ & & 10.2 \\
\hline 21 & 41 & 21 & $\begin{array}{l}\text { The first pair of external gills develops up to six } \\
\text { branches in this species. The second pair of external } \\
\text { gills is small and unbranched. The tail becomes } \\
\text { elongated (Fig. 2G). }\end{array}$ & & 11.8 \\
\hline 22 & 41 & 22 & $\begin{array}{l}\text { The external gills enlarge. The eyes contain pigment. } \\
\text { There is blood circulation in the tail fin (Fig. } 2 \mathrm{H} \text { ). }\end{array}$ & & 12.8 \\
\hline 23 & 43 & 23 & $\begin{array}{l}\text { The external gills reach their full size. The opercular } \\
\text { fold is forming. The eyes and the body are pigmented } \\
\text { (Fig. 2l). }\end{array}$ & & 13.8 \\
\hline 24 & 44 & 24 & $\begin{array}{l}\text { The external gills are visible only on the left side. The } \\
\text { operculum is closed on the right side (not shown). }\end{array}$ & & 16.9 \\
\hline 25 & 45 & 25 & $\begin{array}{l}\text { The spiracle is formed. The embryos hatch and have } \\
\text { the appearance of a tadpole (Fig. } 2 \mathrm{~L}, \mathrm{M}, \mathrm{N} \text { ). }\end{array}$ & & 20.0 \\
\hline
\end{tabular}

${ }^{1}$ The stages of development for $C$. machalilla $(C)$ are compared to the table of stages of $X$ laevis $(\mathrm{X})$ and to the general staging table for frogs $(\mathrm{G})$. The approximate correspondence between the developmental stages of $X$. laevis (Nieuwkoop and Faber, 1994) and the general staging table for frogs (Gosner, 1960) is according to Schlosser and Roth (1997). The embryos were maintained at room temperature $\left(18-23^{\circ} \mathrm{C}\right)$ in a humid chamber. tadpole by the time of hatching (s. 25; Table 1). The optic vesicles were small in $C$. machalilla embryos of s. 17-21 (Fig. 2 A-C,G). At s. 22-23 dark pigment accumulated in the eyes and body (Fig. $2 \mathrm{H}, \mathrm{I}$; Table 1).

In s. 18, the branchial arches appeared as three bulges on each side of the head (Fig. 2 B,C; Table 1). In s. 19, the buds of the first pair of external gills develop in the branchial region (Fig. 2D) and soon thereafter, these gill buds divided into four small branches (Fig. 2E). Simultaneously, the gills buds of the second pair of gills were observed (Fig. 2E; Table 1). In s. 20, the external gills grew and displayed blood circulation (Fig. 2F; Table 1). The external gills continue to grow in s. 21-22 (Fig. $2 \mathrm{H}$ ) and reached their maximum size in s. 23 (Fig. 2l; Table 1). Thereafter, the opercular fold gradually covered the external gills (s. 24, not shown) until they retracted completely into the opercular cavity in s. 25 .

Colostethus machalilla embryos of s. 23-25 developed the operculum, as in other anurans (Gosner, 1960). The opercular fold became visible in s. 23 (Table 1) and covered the external gills on the right in s. 24 (Table 1). The operculum was completely formed by s. 25 and the spiracle became visible on the left (Fig. $2 \mathrm{~L}-\mathrm{N}$; Table 1). Embryos of $C$. machalilla hatched at s. 25 (Fig. $2 \mathrm{~L}-\mathrm{N}$; Table 1). At hatching, the mouth had darkly pigmented teeth (Fig. $2 \mathrm{~N}$ ), the intestine was coiled (Fig. $2 \mathrm{~L}, \mathrm{~N}$ ), the body had dark pigment and the embryo had the appearance of a tadpole (Fig. 2 $\mathrm{L}-\mathrm{N}$; Table 1). Most tadpoles metamorphosed in about 5 months at $18-21^{\circ} \mathrm{C}$ (range of $2-7$ months, based on 66 tadpoles from 9 egg clutches). The new frogs began to vocalize after 8-12 months and egg production started 24 months after metamorphosis.

\section{Morphology of early development}

Formation and expansion of the blastocoel (s. 7-12): The external appearance of the large celled blastula with its opaque blastocoel roof (s. 7) is shown as reference (Fig. 3A). At this stage, the internal large vegetal cells were loosely arranged, whereas the superficial cells were tightly packed (Fig. 3B). The blastocoel gradually enlarged until s. 12 (Fig. 3 C,E,F,H). In embryos of s. 78 , the blastocoel roof consisted of about 7 cell diameters. Simultaneously with the expansion of the blastocoel, its roof became thinner. At s. 10 (Fig. 3D), the roof of the blastocoel had a thickness of three cell diameters (Fig. 3 E,F) and was opaque (not shown). A portion of the blastocoel roof became translucent at S. 11 (not shown) and the translucent area enlarged at s. 12 (Fig. $3 \mathrm{G}, \mathrm{H}$ ). At this stage the roof was reduced to a translucent cell monolayer (Fig. 3I). Yolky cells of the mesendoderm (as defined for $X$. laevis by Ibrahim and Winklbauer, 2001) moved along the inner surface of the blastocoel roof during s. 12 . This process gradually reduced the translucent region until it became totally covered with opaque yolky cells in advanced s. 12 embryos (not shown).

Internal morphology of the gastrula (s. 10-13): At s. 10 the dorsal blastopore lip (Fig. 3D) had a subequatorial location (Fig. 3 $\mathrm{E}, \mathrm{F}$ ). Blastopore closure reduced the size of the yolk plug (Fig. 3 $\mathrm{G}, \mathrm{K}$ ). Internally, the blastopore lips were thick (Fig. $3 \mathrm{H}$ ) due to the accumulation of small cells (Fig. $3 \mathrm{~J}$ ). The embryo surface was covered by a monolayer of small cells, whereas the yolk plug and endodermal cells were large (Fig. 3J). As the blastopore closed, a small dorsal archenteron became visible (Fig. 3L), which did not enlarge until the late s. 12, when the yolk plug was very small (not shown). The archenteron reached its full size at s. 13 and the remnants of the blastopore lips made up a thick circumblastoporal 
collar (as defined by Hausen and Riebesell, 1991; Fig. 3M). Externally, the embryos of $C$. machalilla do not form an embryonic disk, although the thickened blastopore lips resemble the embryonic disk of $G$. riobambae (del Pino and Elinson, 1983). The surface of the embryos was stained as explained in Elinson and del Pino (1985). Further analysis of the $C$. machalilla morphology of gastrulation is in progress.

Morphology of the neural tube, notochord and somites (s. 1319): The neural plate and the notochord were first recognized in s. 13 (Fig. 1L; Benítez and del Pino, 2002), whereas the somites became visible at a much later stage (s. 17). The first detection of antigen 2G9 (Jones and Woodland, 1989) and NCAM protein

Fig. 3. The morphology of early development in C. machalilla. Stages of development are placed in the upper right hand corner of each image. The animal pole is oriented towards the front in $(A)$ and towards the top in $(B, C, E-$ $J, L)$. The vegetal views of the embryos are given in $(D, K)$. Dorsal is oriented towards the right in $(E, F, H, J, L)$, towards the top in (M-R) and towards the left in (S). Whole embryos are shown in $(A, D, G, K)$. Bisected embryos are shown in $(C, H)$. Sections of 50-100 $\mu$ m are shown in $(B, E, F, I, J, L, M, O$, R). Whole mount immunostained embryos are shown in (N, $P, Q, S)$. Nuclei were stained with Hoechst and viewed with fluorescent optics in $(F, I, J, R)$. The shape of the blastocoel was preserved in Smith's fixative (A, C-K), whereas the blastocoel and archenteron collapsed in embryos fixed in MEMFA (B, M). (A) External view of an early blastula. The animal pole has dark pigment. (B) Internal view of an early blastula. The blastocoel (b) roof consists of several layers of small cells, while the blastocoel floor has loosely arranged large blastomeres. (C) Internal view of a mid blastula. The blastocoel floor cells are smaller than in (B). (D) External view of the dorsal blastopore lip (dl) of an early gastrula. This embryo is comparable to Fig. $1 \mathrm{G}$. (E) Sagittal section of an early gastrula. The dorsal blastopore lip is subequatorial. A thinner roof covers the large blastocoel. The cavity observed in the vegetal region is an artifact of fixation. (F) The nuclei of the same section shown in (E). The blastocoel roof consists of 2-3 cells in thickness. (G) External view of a late gastrula. The blastocoel roof is translucent. $(\mathbf{H})$ Internal view of a late gastrula. The blastocoel is large and covered by a very thin roof. The blastopore lips are visible and a small archenteron is present on the dorsal side. (I) The blastocoel roof of a late gastrula consists of a single cell layer. (J) Sagittal section of the late gastrula. The blastopore lips are thick and contain many cells. (K) External view of a late gastrula. The yolk plug is smaller than in (G) and the blastocoel roof is still translucent (not shown). (L) Sagittal section of an embryo as in (K). The blastopore lips are thick and a small archenteron is visible on the dorsal side. (M) Sagittal section of slit blastopore stage embryo. The blastopore lips have fused, forming an enlarged circumblastoporal collar. The archenteron is greatly enlarged. This embryo was immunostained with anti-Bra and the Bra positive cells (in purple) are concentrated in the circumblastoporal collar. (N) An s. 16 embryo immunostained with antibody 2G9. The cranial neural crest is visible. (0) An s. 18 embryo immunostained with antibody 2G9. The deep location of the neural crest is seen in this cross section of the posterior brain. (P) An s. 17 embryo immunostained with anti-NCAM to detect the neural tube. The facial nerves (VII) run parallel to the rostral limit of the otocysts. Rhombomere boundaries are faintly visible. Otocysts are located opposite rhombomere 4. (Q) An s. 17 embryo immunostained with anti-Bra to detect the notochord and tail bud. This figure is reprinted from Benitez and del Pino (2002). (R) Nuclear staining of a cross section of the trunk of an s. 16 embryo. The neural tube and notochord are evident, while somites cannot be distinguished. (S) An s. 19 embryo immunostained with antibody 12/101 to detect the somites. Abbreviations: vii, facial nerve; a, archenteron; b, blastocoel; dl, dorsal lip; $n$, notochord; $n c$, neural crest; nt, neural tube; 0 , otocyst; r4, rhombomere 4; s, somite; tb, tail bud; vl, ventral lip; yp, yolk plug. Bars, 50 $\mu \mathrm{m}$ in $\mathrm{I} ; 100 \mu \mathrm{m}$ in $N, P-R ; 200 \mu \mathrm{m}$ in $B-D, L, O ; 400 \mu \mathrm{m}$ in $A, F, H, J, M, S ; 500$ $\mu m$ in $G, E, K$.
(Rutishauser and Jessell, 1983; Watanabe et al., 1986) in whole mount immunostaining occurred at s. 14 (not shown). The cranial neural crest was identified by the $2 \mathrm{G} 9$ immune reaction in $\mathrm{s} .16$ (Fig. 3N) and in a cross section of s. 18 (Fig. 3O). At this stage, $2 \mathrm{G9}$ also marks the trunk neural crest (not shown). The neural tube was NCAM positive (s. 17; Fig. 3P). In this NCAM immunostained embryo, differential staining of the rhombomeres was observed; the facial nerve VII and the spinal nerve roots were visible (Fig. 3P).
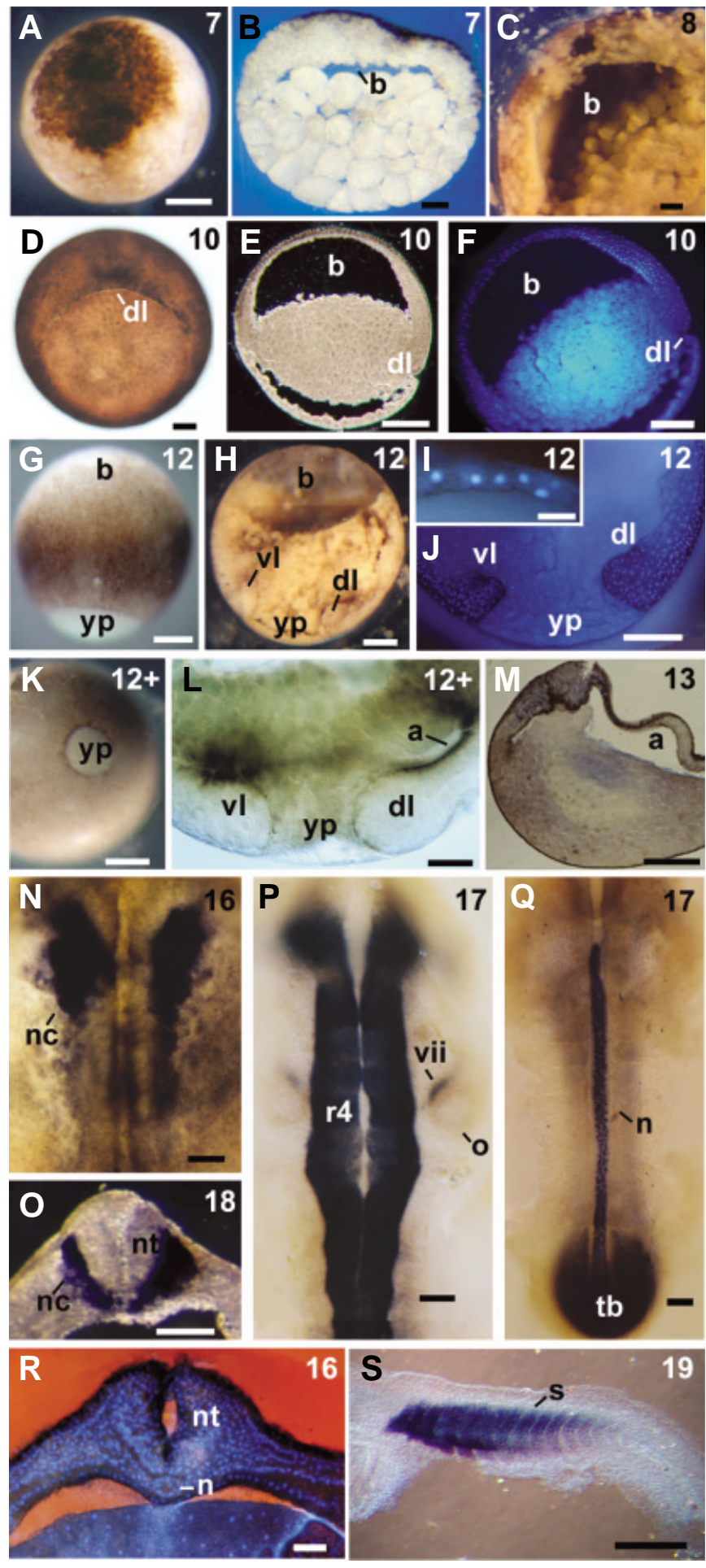

$16 \mathrm{~S}$

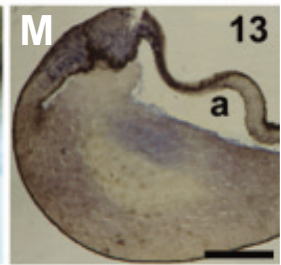

$p$
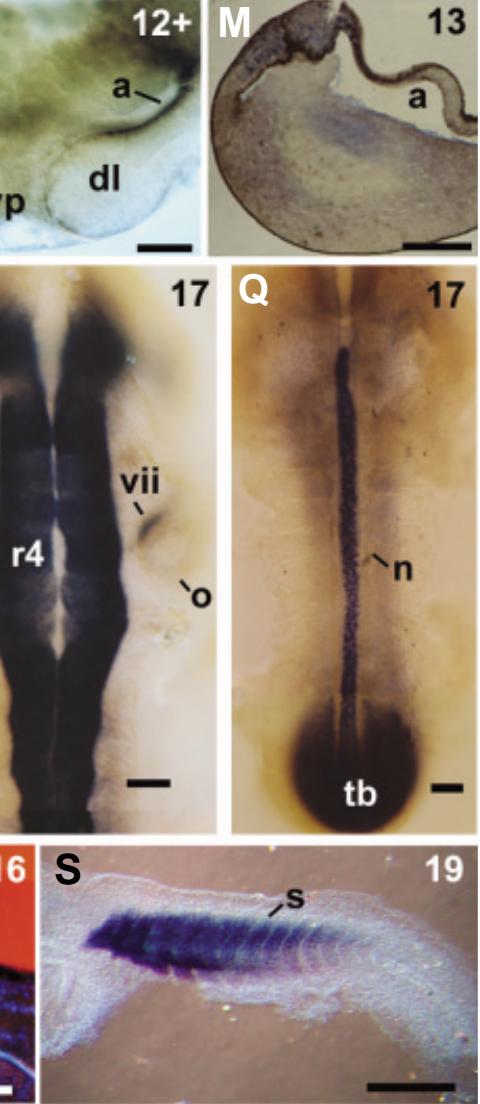
The immune detection with anti-Bra of an embryo of similar stage revealed the notochord and tail bud (Fig. 3Q). A representative section of the trunk in a s. 16 embryo showed a prominent neural tube, a small notochord and an absence of somites (Fig. 3R). In contrast, cross-sections of the $X$. laevis neurulae reveal that the notochord and somites are large and conspicuous whereas the neural tube is relatively small (Davidson and Keller, 1999). In $C$. machalilla, the somites became morphologically visible at s. 17, (Fig. 2A) and the expression of antigen 12/101 and myosin (not shown) occurred at the late s. 17 (not shown). At s. 19, the anterior somites were 12/101 positive whereas the posterior somites and tail bud were negative (Fig. 3S).

\section{Development of other dendrobatid frogs}

The eggs of $C$. machalilla were the smallest and the least pigmented of the dendrobatids analyzed, whereas eggs of other dendrobatid frogs such as Colostethuskingsburyiand Epipedobates tricolor(Syn: Phylobates tricolor) reached $2 \mathrm{~mm}$ in diameter and were darker (not shown). Although the developmental pattern of six additional species was basically similar with the development of $C$. machalilla, we detected differences in developmental time. For example, E. tricolordevelops somewhat faster than C. machalilla. A major deviation occurs in the branching of the external gills. In contrast with the six-gill branches of $C$. machalilla embryos (Fig. $2 \mathrm{I}$ ), the first gill pair of $E$. tricolor had a total eight branches (Fig. 2J) and Colostethus marchesianus developed only four-gill branches (Fig. 2K). The second pair of gills remained small and unbranched in embryos of these frogs.

\section{Discussion}

Although frogs have a wide array of reproductive modes (Duellman and Trueb, 1986), study of development is restricted to only those species that can reproduce in the laboratory. Dendrobatid frogs can be maintained in captivity and reproduce frequently (Zimmermann and Zimmermann, 1987). It is therefore surprising that the development of these frogs has not been previously analyzed. As bases for further analysis, this work provides a normal table of development and the methods for the handling of C. machalilla embryos. It shows that the development of this frog shares morphological characteristics (Fig. 1 A-O) and the expression of neural, notochord and somite molecular markers with $X$. laevis and other frogs (Fig. 3 N-Q, S; del Pino and Medina, 1998; Benítez and del Pino, 2002). Embryos of $C$. machalillahave a gray crescent and develop a conspicuous dorsal blastopore lip, features that indicate the dorsal side during early development, as in $X$. laevis. There are, however, significant differences. Colostethus machalilla develops somewhat more slowly than $X$. laevis (Table 1; Nieuwkoop and Faber, 1994). The formation of the archenteron, somite and neural development are retarded in comparison with $X$. laevis. Eye formation is also retarded in C. machalilla in comparison with Rana pipiens and X. laevis (Shumway, 1940; Nieuwkoop and Faber, 1994). At the tail bud stage, the optic vesicles of $C$. machalilla are less conspicuous than in $X$. laevis (Fig. 2A; Table 1; Nieuwkoop and Faber, 1994). The delay of eye development in $C$. machalilla may be related to its terrestrial mode of early development, which results in the retardation of the free-living phase until s. 25 (Fig. 2L; Table 1). There are distinctive features in the blastula and gastrula of $C$. machalilla. The blastocoel, which in $\mathrm{s.} 7$ embryos is small (Fig. 3B), enlarges during the blastula and gastrula stages until its roof consists of a single cell layer by s. 12 (Figs. $3 \mathrm{C}, \mathrm{E}, \mathrm{H}, \mathrm{I}$ ). The translucent blastocoel roof allows detection of the mensendoderm advancement in living embryos. A similar thinning of the blastocoel roof occurs in G. riobambae(Elinson and del Pino, 1985). The significance of the blastocoel roof thinning in $C$. machalilla and $G$. riobambae is unknown. In contrast, the blastocoel roof in $X$. laevis contains two cell layers and it is relatively opaque (Hausen and Riebesell, 1991). As the blastocoel roof becomes thinner, a dorsal blastopore lip is formed sub equatorially in C. machalilla (s. 10; Fig. 3E). The position of the dorsal blastopore lip varies among frogs. It is subequatorial in $X$. laevis and it forms at the equator of $E$. coqui. In embryos of $G$. riobambae, a frog that forms an embryonic disk, a dorsal blastopore lip has not been detected, but the blastopore is subequatorial (reviewed in del Pino and Elinson, 2003). The developmental significance of blastopore lip location may be related to the distribution of the meso-endodermal and dorsal determinants in eggs of different frogs (del Pino and Elinson, 2003).

In $X$. laevis, elongation of the archenteron and notochord and neural plate formation start in the mid gastrula and are mainly driven by dorsal convergence and extension (reviewed in Keller 1999). These events occur after blastopore closure in C. machalilla suggesting retardation of the dorsal convergence and extension movements. In G. riobambae and $E$. coqui similar delays have been observed (del Pino, 1996; Ninomiya, et al., 2001). The great thickness of the blastopore lips in the $C$. machalillaand $G$. riobambae gastrulae is another characteristic that may result from the delay in dorsal convergence and extension. The thick blastopore lips of $G$. riobambae form an embryonic disk (reviewed in del Pino and Elinson, 2003). In the small and rapidly developing eggs of $X$. laevis, small cells do not accumulate at the blastopore lips and hence an embryonic disk is not formed. Although $C$. machalilla does not form an embryonic disk the study of its thick blastopore lips may reveal modifications in the gastrulation process. The external morphology of $C$. machalilla embryos is not unusual (Fig. 1 A-O). The expression of Bra (Benítez and del Pino, 2002), internal features of the blastula and gastrula and the retardation of developmental events, however, differ from $X$. laevis. Further studies are therefore important to determine the mechanisms underlying these developmental variations.

\section{Materials and Methods}

\section{Maintenance of frogs and tadpoles}

Colostethus machalillaand six other species of dendrobatid frogs were successfully maintained in captivity. The additional species analyzed were Colostethus awa, Colostethus infraguttatus, Colostethus kingsburyi, Colostethus marchesianus, Epipedobates boulengeri and Epipedobates tricolor (according to Santos et al., 2003). Six to ten adults of $C$. machalilla were kept inside each one of 5 glass terraria of $50 \times 25 \times 30 \mathrm{~cm}$. The terraria were covered with plastic film (of the type used to wrap food) and received natural light conditions of 12-hours light and 12-hours darkness. The temperature fluctuated between $23^{\circ} \mathrm{C}$ at midday and $18^{\circ} \mathrm{C}$ at night. The terrarium floor consisted of soil, dry leaves and Tradescantia plants. Each terrarium had a shallow container with water and the water was changed weekly. Every other day, water was sprayed on the terraria and the frogs were fed. The major diet item was Drosophila dusted with powdered multivitamins and minerals (Centrum from A to Zinc, Whitehall-Robins, Madison, NJ, U.S.A.). Additional food consisted of Colembolae, maize 
weevils and newly hatched crickets. Newly metamorphosed frogs were fed Colembolae and Drosophila vestigial wing mutants.

Photographic film containers were provided as nesting sites to facilitate removal and manipulation of embryos. If the eggs were left in the nest, the male guarded them, until the tadpoles hatched. At hatching, the father transported the tadpoles to the water, as mentioned before. To avoid predation by the adults, we transferred the tadpoles to a different container. About ten tadpoles per liter of water were maintained in chlorine-free water and fed dry Taraxacumleaves and fish food. The water was changed every week.

\section{Culture and handling of embryos}

Embryos of $C$. machalilla were cultured in two ways: (1) in a humid chamber and (2) submerged in $15 \%$ Steinberg's solution (Rugh, 1962). The humid chamber consisted of a $5 \mathrm{~cm}$ Petri dish with a bottom covered by wet filter paper and a small piece of plastic foil of $2 \times 2 \mathrm{~cm}$, to prevent sticking of the egg jelly to the filter paper. Newly fertilized eggs and early cleavage stage embryos were cultured in a humid chamber, whereas embryos from the blastula onward could be equally cultured in $15 \%$ Steinberg's solution. The soil-contaminated egg jelly was removed before culture in $15 \%$ Steinberg's solution. Steinberg's solution contains $58 \mathrm{mM} \mathrm{NaCl}, 0.65 \mathrm{mM}$

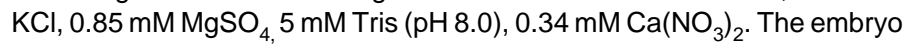
cultures were kept at room temperature $\left(18-23^{\circ} \mathrm{C}\right)$.

\section{Morphology, histology and immunostaining}

Embryos of $C$. machalillawere fixed in MEMFA buffer (Harland, 1991), Dent's fixative (Dent et al., 1989), or in Smith's fixative (Brown et al., 2002). The blastocoel and archenteron did not collapse in Smith's fixative in contrast with the other solutions. For this reason, embryos fixed in Smith's fixative were preferentially used to analyze external and internal morphology. To describe the stages of development, living and fixed embryos were observed and photographed. O.D. Pérez did drawings of representative stages of development.

To study the internal morphology, embryos were embedded in $6 \%$ agarose and bisected with a knife. Sections of 50-100 $\mu \mathrm{m}$ were produced with a Vibratome 1000 (Technical Products International, Inc. St. Louis MO) as described by del Pino (1996). The sections were cleared and mounted in benzyl benzoate/benzyl alcohol (2:1). Some sections were stained with Hoechst 33258 (Sigma-Aldrich, St. Louis, MO, USA) and examined with fluorescent optics (according to Brown, et al., 2002).

To determine the characteristics of neural development embryos were immunostained in whole mount, with the following antibodies: (1) monoclonal antibody (4d) against NCAM from chick brain membranes (Watanabe et al., 1986) and (2) monoclonal antibody 2G9 against a neural antigen from $X$. laevis (Jones and Woodland, 1989) were used to study neural development. The rabbit polyclonal antibody against Bra (Kispert and Herrmann, 1994) was used to detect the notochord. The somites were identified with the monoclonal antibody 12/101 (Kintner and Brockes, 1984). For immunostaining with antibody $4 d, 2 G 9$ and 12/101, the embryos were fixed in Dent's fixative and for immunostaining with antiBra, embryos were fixed in MEMFA buffer. The secondary antibodies conjugated to alkaline phosphatase were sheep anti-mouse $\lg G$ and sheep anti-rabbit IgG (Boehringer Mannheim GmbH, Mannheim, Germany). The immunostaining procedure is described in Benítez and del Pino (2002). Some immunostained embryos were sectioned as described above. Whole mount preparations, bisected embryos and sections were analyzed and photographed with a Stemi SV 6 and with an Axiophot (Carl Zeiss, Oberkochen, Germany).

\section{Acknowledgements}

We thank L. Coloma and S. Ron for the identification of frogs and the provision of several dendrobatid frogs. We thank L. E. López for his help in the collection of frogs. For their help we express gratitude to $F . D$. Brown, F. E. Sáenz and D. Donoso. We thank I. Dawid, E. Jones and B. Herrmann for the donation of antibodies. This work was supported by grants from the Pontificia Universidad Católica del Ecuador and grant number PFN-034 from FUNDACYT, Ecuador.

\section{References}

BENÍTEZ, M.-S. and DEL PINO, E.M. (2002). The expression of Brachyury during development of the dendrobatid frog Colostethus machalilla. Dev. Dyn. 225: 592596.

BROWN, F. D., DEL PINO, E. M. and KROHNE, G. (2002). The Bidder's organ in the toad Bufo marinus: effects of orchidectomy on the morphology and expression of lamina-associated polypeptide 2. Dev. Growth Differ. 44: 527-535.

COLOMA, L.A. (1995). Ecuadorian frogs of the genus Colostethus (Anura: Dendrobatidae). Misc. Public. Nat. History Museum. University ofKansas, Lawrence 87: 1-74.

DALY, J.W., MYERS, C.W. and WHITTAKER, N. (1987). Further classification of skin alkaloids from neotropical poison frogs (Dendrobatidae), with a general survey of toxic/noxious substances in the Amphibia. Toxicon 25: 1023-1095.

DAVIDSON, L.A. and KELLER, R.E. (1999). Neural tube closure in Xenopus laevis involves medial migration, directed protrusive activity, cell intercalation and convergent extension. Development 126: 4547-4556.

DEL PINO, E.M. (1996). The expression of Brachyury (T) during gastrulation in the marsupial frog Gastrotheca riobambae. Dev. Biol. 177: 64-72.

DEL PINO E. M. and ELINSON R.P. (1983). Gastrulation produces an embryonic disc, a novel developmental pattern for frogs. Nature 306: 589591.

DEL PINO, E.M. and ELINSON, R.P. (2003). The organizer in amphibians with large eggs: Problems and perspectives. In: The Vertebrate Organizer, (ed. H. Grunz), Springer Verlag, pp. 359-374.

DEL PINO, E. M. and MEDINA, A. (1998). Neural development in the marsupial frog Gastrotheca riobambae. Int. J. Dev. Biol. 42: 723-731.

DENT, J.A., POLSON, A.G. and KLYMKOWSKY, M.W. (1989). A whole-mount immunocytochemical analysis of the expression of the intermediate filament protein vimentin in Xenopus. Development 105: 61-74.

DUELLMAN, W.E. and TRUEB, L. (1986). Biology of Amphibians. McGraw-Hill.

ELINSON, R.P. and DEL PINO, E.M. (1985). Cleavage and gastrulation in the eggbrooding, marsupial frog, Gastrotheca riobambae. J. Embryol. Exp. Morph. 90: 223-232.

GONT, L.K., STEINBEISSER, H., BLUMBERG, B. and DE ROBERTIS, E.M. (1993). Tail formation as a continuation of gastrulation: the multiple cell populations of the Xenopustailbud derive from the late blastopore lip. Development 119: 991-1104.

GOSNER, K.L. (1960). A simplified table for staging anuran embryos and larvae with notes on identification. Herpetologica 16: 183-190.

HARLAND, R.M. (1991). In situ hybridization: an improved whole-mount method for X. laevis embryos. Meth. Cell Biol. 36: 685-695.

HAUSEN, P. and RIEBESELL, M. (1991). The early development of Xenopus laevis. Springer-Verlag.

IBRAHIM, H. and WINKLBAUER, R. (2001). Mechanisms of mesendoderm internalization in the Xenopusgastrula: lessons from the ventral side. Dev. Biol.240: 108122.

JONES, E.A. and WOODLAND, H.R. (1989). Spatial aspects of neural induction in Xenopus laevis. Development 107: 785-791.

KELLER, R. (1999). The origin and morphogenesis of amphibian somites. Curr. Top. Dev. Biol. 47: 183-246.

KINTNER, C.R. and BROCKES, J.P. (1984). Monoclonal antibodies identify blastemal cells derived from dedifferentiating muscle in newt regeneration. Nature 308:67-69.

KISPERT, A. and HERRMANN, B.G. (1994). Immunohistochemical analysis of the Brachyury protein in wild type and mutant mouse embryos. Dev. Biol. 161: 179193.

NIEUWKOOP, P.D. and FABER, J. (1994). Normal Table of X. laevis laevis (Daudin). Garland Publishing.

NINOMIYA, H., ZHANG, Q. and ELINSON, R.P. (2001). Mesoderm formation in Eleutherodacty/us coqui. body patterning in a frog with a large egg. Dev. Biol. 236: 109-123.

QUIGUANGO-UBILLÚS, A. (2000). Brutpflege bei Pfeilgiftfröschen. Draco TerraristikThemenheft 1: 16-23. 
RUGH, R. (1962). Experimental Embryology: techniques and procedures. $3^{\text {rd }}$ edition. Burgess Publishing, p. 15.

RUTISHAUSER, U. and JESSELL, T. M. (1983). Cell adhesion molecules in vertebrate neural development. Physiol. Rev. 68: 819-859.

SANTOS, J.C., COLOMA, L.A. and CANNATELLA D.C. (2003). Multiple, recurring origins of aposetism and diet specialization in poison frogs. Proc. Nat. Acad. SCl. USA. 100: 12792-12797.

SCHLOSSER, G. and ROTH, G. (1997). Evolution of nerve development in frogs. Brain Behav. Evol. 50: 61-93.

SHUMWAY, W. (1940). Stages in the normal development of Rana pipiens. Anat. Rec. 78: 139-146.

SMITH, J.C., PRICE, B.M.J., GREEN, J.B.A., WEIGEL, D. and HERMANN, B.G. (1991). Expression of a Xenopus homolog of Brachyury $(T)$ is an immediate-early response to mesoderm induction. Cel/67: 79-87.
VINCENT, J.P., OSTER, G.F. and GERHART, J.C. (1986). Kinematics of gray crescent formation in Xenopus eggs: The displacement of subcortical cytoplasm relative to the egg surface. Dev. Biol. 113: 484-500.

WATANABE, M., FRELINGER, A.L. and RUTISHAUSER, U. (1986) Topography of NCAM structural and functional determinants. I. Classification of monoclonal antibody epitopes. J. Cell Biol. 103: 1721-1727.

ZIMMERMANN, H. and ZIMMERMANN, E. (1987). Mindestanforderungen für eine artgerechte Haltung einiger tropischer Anurenarten. Zeitschrift des Kölner Zoo30: 61-71.

Received: April 2004 Reviewed by Referees: June 2004 Modified by Authors and Accepted for Publication: June 2004 Edited by: George M. Malacinski 